\title{
Evaluation of the groundnut model PNUTGRO for crop response to water availability, sowing dates, and seasons
}

\author{
Piara Singh ${ }^{\text {a,* }}$, K.J. Boote ${ }^{b}$, A. Yogeswara Rao ${ }^{c}$, M.R. Iruthayaraj ${ }^{\text {d }}$, A.M. Sheikh ${ }^{e}$, \\ S.S. Hundal ${ }^{\text {f }}$, R.S. Narang ${ }^{f}$, Phool Singh ${ }^{g}$ \\ "Soils and Agroclimatology Division, International Crops Research Institute for the Semi-Arid Tropics (ICRISAT), Patancheru, \\ Andhra Pradesh 502 324, India \\ ${ }^{b}$ Agronomy Department, Institute of Food and Agricultural Sciences, University of Florida, Gainesville, FL 32611-0311, USA \\ ' Andhra Pradesh Agricultural University, Anantapur, Andhra Pradesh, India \\ ${ }^{-}$Water Technology Center, Tamil Nadu Agricultural University, Coimbatore, Tamil Nadu, India \\ - Gujarat Agricultural University, Anand, Gujarat, India \\ 'Punjab Agricultural University, Ludhiana, Punjab, India \\ 'Haryana Agricultural University, Hisar, Haryana, India
}

Received 20 June 1994; accepted 24 September 1994

\begin{abstract}
Field experiments were conducted during the period from 1987 to 1992 at four locations in India to collect data to test and validate the groundnut (Arachis hypogaea L.) model PNUTGRo for its capability to predict phenology, growth, and yield. Groundnut (cv. Robut 33-1) was grown during the rainy and post-rainy seasons at these sites under various management practices such as sowing dates and differential irrigation. Using the data sets from several years, the model was calibrated for genetic coefficients of cvs. Robut 33-1 and TMV 2 determining their phenology and growth, as well as for soil physical parameters influencing the soil water balance. The model was validated for cv. Robut 33-1 against independent data sets obtained from field experiments conducted during the later years. The model predicted the occurrence of flowering and podding within \pm 5 days of observed values at locations where growth stages were recorded most frequently. Predictions of growth stages beyond podding were less accurate because of difficulties, associated with the indeterminate nature of the crop, to record growth stages after pod growth has started in the soil. Changes in vegetative growth stages, total dry matter accumulation, growth of pods and seeds, and soil moisture were predicted accurately by the model. Predicted pod yields were significantly correlated $\left(r^{2}=0.90\right)$ with observed yields. These results indicate that under biotic stress-free situations, the model PNUTGRO can be used to predict groundnut yields in different environments as determined by season, sowing date, and moisture regimes.
\end{abstract}

Keywords: Arachis; Groundnut; Modelling; Simulation; Yield prediction

\section{Introduction}

Groundnut (Arachis hypogaea L.) is grown in India in diverse agroclimatic environments. Rainfall in these

* Corresponding author. regions varies from 400 to $800 \mathrm{~mm}$ during the season and the soils range from low water-holding capacity Alfisols to high water-holding capacity Vertisols. Average groundnut yield in these environments is $0.81 \mathrm{t} / \mathrm{ha}$ (Virmani et al., 1991), which is well below potential 
yields. Rainfall is a major factor causing spatial and temporal variations in groundnut yields.

To assess the scope for increasing groundnut production in India we need to know the yield potentials and understand factors limiting yield of groundnut. Such understanding can be achieved by conducting multilocation field experiments over several years to evaluate the crop management practices in different environments. An alternative approach is to use validated crop growth models and historical climatic data to evaluate various crop management strategies for locations or regions on a long-term basis. To meet these objectives the groundnut model PNUTGRO was developed by scientists at the University of Florida, USA (Boote et al., 1986, 1987, 1992; Boote and Jones, 1988). This model has been tested for temperate regions where the average production levels of groundnut are high ( 2.2 to $2.8 \mathrm{t} / \mathrm{ha}$ ) (Isleib and Wynne, 1992) and constraints to production are different than those in the semi-arid tropics. It is therefore appropriate that the model be tested and validated before it is applied in semi-arid tropical environments. The objective of this paper is to evaluate the performance of the groundnut model PNUTGRO under different levels of water availability in various seasons and sowing dates at four locations in semi-arid tropical India where groundnut is grown. The capability of the model to predict phenology, growth processes, soil water balance, and crop yields will be assessed.

\section{Model description}

The groundnut model PNUTGRO is a process-level model developed by an interdisciplinary research team (Boote et al., 1986, 1987) to simulate growth and yield of groundnut. The major components of the model are vegetative and reproductive development, carbon balance, nitrogen balance, and water balance modules. The basic structure of the model and the underlying differential equations have been explained in detail by Wilkerson et al. (1983) and Boote et al. (1987). Various processes of the model relevant to this study are briefly described below.

\subsection{Crop development}

PNUTGRO initiates the simulation of development as soon as planting has occurred. The model predicts the germination period from planting to emergence, first full leaf expansion, start of flowering, first pod occurrence, beginning of seed filling, end of leaf growth and expansion, end of pod growth and expansion, physiological maturity, and harvest maturity (Boote, 1982). The model also predicts leaf area development and vegetative node formation on the main stem. Each of the stages mentioned earlier has a thermal unit threshold value which is defined in the file containing cultivar-specific coefficients (genetic coefficients). For most of the stage definitions in the model only a temperature effect is included. The temperature effect is based on a temperature-response curve, rather than a degree day concept as used in many models. It is assumed that development will occur at an optimum or maximum relative rate of 1 (photothermal days per calendar day) for a certain optimum temperature range. At temperatures below or above this range, the relative development rate is lower, causing a delay in the overall development process.

The hedgerow version of the PNUTGRO model uses two kinds of temperature response functions for crop development: (1) the linear function for vegetative stage progression defined by base temperature (Tbase), optimum temperature range (Topt), and maximum temperature (Tmax), and (2) the full sine function for reproductive development which is a function of base temperature and optimum temperature. For the vegetative stages Tbase $=13.5^{\circ} \mathrm{C}$, Topt ranges from 28.0 to $35^{\circ} \mathrm{C}$, and $T \max =55^{\circ} \mathrm{C}$. Three different full sine functions were used to calculate physiological days from emergence to flowering (Tbase $=9.5^{\circ} \mathrm{C}$ and Topt $=27.2^{\circ} \mathrm{C}$ ), flowering to pod-initiation ( Tbase $=9.5^{\circ} \mathrm{C}$ and $\mathrm{Topt}=25.8^{\circ} \mathrm{C}$ ), and beginning seed growth to physiological maturity (Topt $=5.0^{\circ} \mathrm{C}$ and Topt $=25.9^{\circ} \mathrm{C}$ ). The base and optimum temperatures were calibrated by using the phenology data of the calibration experiments conducted at four sites (Table 1).

\subsection{Carbon balance}

The model predicts total canopy photosynthesis on a daily basis as a function of daily total photosynthetic active radiation, converted from daily total solar radiation. PNUTGRO includes the hedgerow sub-model (Boote et al., 1992) which predicts light interception and canopy photosynthesis of hedgerow canopies to 
'able 1

'articulars of the field experiments which contributed the data sets sed for model calibration and validation

\begin{tabular}{lllll}
\hline ieason Sowing date & Total irrigation applied $(\mathrm{mm})$ & $\begin{array}{l}\text { Seasonal } \\
\text { reainfall }\end{array}$ \\
\cline { 2 - 4 } & RF & IR & PIR & $(\mathrm{mm})$
\end{tabular}

\begin{tabular}{|c|c|c|c|c|c|}
\hline \multicolumn{6}{|c|}{$\begin{array}{l}\text { For model calibration: } \\
\text { Inand }\end{array}$} \\
\hline \multirow[t]{2}{*}{ ? 1987} & $02 \mathrm{Jul}$ & 0 & $200(4)^{n}$ & - & 278 \\
\hline & $17 \mathrm{Jul}$ & 0 & $200(4)$ & - & 282 \\
\hline \multicolumn{6}{|c|}{ 'atancheru } \\
\hline \multicolumn{2}{|c|}{ 'R 1987 05 Jan } & - & $445(12)$ & $210(6)$ & 12 \\
\hline & $21 \mathrm{Jan}$ & - & $445(12)$ & $340(9)$ & 53 \\
\hline \multirow[t]{3}{*}{ ২ 1988} & 27 Jun & - & $20(1)$ & $20(1)$ & 778 \\
\hline & $20 \mathrm{Jul}$ & 0 & $160(9)$ & - & 642 \\
\hline & 06 Aug & 0 & $220(12)$ & - & 513 \\
\hline ? 1989 & 24 Jun & - & $246(10)$ & $31(1)$ & 909 \\
\hline \multicolumn{6}{|c|}{ Inantapur } \\
\hline \multirow[t]{2}{*}{1987} & 04 Aug & 0 & $150(3)$ & - & 387 \\
\hline & 03 Sep & 0 & $110(3)$ & - & 400 \\
\hline \multicolumn{6}{|c|}{ Toimbatore } \\
\hline ? 1987 & (02 Jul & - & $450(9)$ & $350(7)$ & 121 \\
\hline ? 1988 & 29 Jun & - & $350(7)$ & $250(5)$ & 243 \\
\hline \multicolumn{6}{|c|}{$\begin{array}{l}\text { I. For model validation: } \\
\text { Inand }\end{array}$} \\
\hline २ 1988 & $04 \mathrm{Jul}$ & 0 & $50(1)$ & - & 956 \\
\hline \multicolumn{6}{|c|}{ 'atancheru } \\
\hline ? 1984 & $09 \mathrm{Jul}$ & 0 & - & - & 477 \\
\hline ? 1987 & $13 \mathrm{Jul}$ & - & $280(8)$ & $40(1)$ & 405 \\
\hline ? 1990 & 19 Jun & - & $105(2)$ & - & 579 \\
\hline 'R 1990 & $04 \mathrm{Dec}$ & - & $694(16)$ & - & 88 \\
\hline 'R 1991 & $04 \mathrm{Dec}$ & - & $730(12)$ & - & 19 \\
\hline २ 1992 & 27 Jun & - & $170(5)$ & - & 493 \\
\hline \multicolumn{6}{|c|}{ Inantapur } \\
\hline \multirow[t]{2}{*}{ र $1988^{\circ}$} & $12 \mathrm{Jul}$ & 0 & 0 & - & 656 \\
\hline & 12 Aug & 0 & $100(2)$ & - & 656 \\
\hline र 1989 & $11 \mathrm{Jul}$ & 0 & $160(4)$ & - & 602 \\
\hline \multirow[t]{2}{*}{ २ 1990} & 16 Jun & 0 & $200(5)$ & - & 218 \\
\hline & 04 Aug & 0 & $160(4)$ & - & 375 \\
\hline \multicolumn{6}{|c|}{ Joimbatore } \\
\hline 31989 & $04 \mathrm{Jul}$ & - & $300(6)$ & $200(4)$ & 312 \\
\hline 'R 1990 & $11 \mathrm{Jan}$ & - & $430(9)$ & $330(7)$ & 172 \\
\hline
\end{tabular}

$\checkmark=$ Rainy season; $P R=$ Post-rainy season; $R F=$ Rainfed; $\mathrm{R}=$ Irrigated; and $\mathrm{PIR}=$ Partially irrigated; $-=$ Absence of irrigaion treatment; $0=$ No irrigation.

Data in parentheses are the number of irrigations given.

Seasonal rainfall is total rainfall from sowing to harvest.

Iccount for row spacing and plant population effects on crop growth. The model estimates photosynthesis yy the sunlit and shaded leaf area index (LAI) sepaately to compute total canopy photosynthesis. Other rariables considered to affect photosynthetic rate are average daily temperature, nitrogen content of leaves, specific leaf area, and crop water deficit. After daily total photosynthesis is calculated, daily maintenance respiration is subtracted which accounts for daily turnover of proteins. Partitioning to vegetative and reproductive structures is determined based upon development phase. LAI is calculated based upon dry matter partitioned to the leaves, specific leaf area (SLA) of new leaves, and leaves abscised due to senescence. Leaf senescence is predicted as a function of age of the plant. Under drought stress, plants will abort additional leaves in proportion to the severity of the stress. Specific leaf area of new leaf tissue is a function of daily average temperature, daily total radiation, and drought stress.

\subsection{Water balance}

The daily soil-crop water balance in PNUTGRO uses the Ritchie (1985) one-dimensional soil water balance approach, which predicts soil water flow and water uptake for each soil horizon or set of soil layers within a horizon. Each layer has a characteristic drained upper limit (DUL) or field capacity, a lower limit (LL) or permanent wilting point, and a saturated soil water content (SAT). Water flow between layers is based on the following assumptions. If a layer has a water content higher than the DUL, saturated downward flow occurs proportional to the amount of additional soil water above the DUL level. If a layer has a water content between LL and DUL, unsaturated flow occurs proportional to the difference in soil water content between two adjacent soil layers. Unsaturated flow can be both downward and upward. For layers with a soil water content less than LL, no flow occurs. In the lowest soil layer, drainage of excess water from the profile can occur. This water is permanently lost and will not be available for later extraction by the roots: Runoff of water from the soil surface occurs based on the total amount of rainfall and/or irrigation and a runoff coefficient (curve number) as defined by the U.S. Soil Conservation Service (USDA, 1972).

Evapotranspiration (ET) is estimated using procedures defined by Ritchie (1972). Potential evapotranspiration is calculated using an equilibrium evaporation concept as modified by Priestley and Taylor (1972). A relatively simple empirical equation was developed to evaluate the influence of radiation and temperature 
on equilibrium evaporation (Jones and Kiniry, 1986). The equation calculates the approximate daytime net radiation and equilibrium evaporation. Potential ET is calculated as the equilibrium evaporation times 1.1 to account for the effect of unsaturated air. The multiplier is increased above 1.1 to allow for advection when the maximum temperature exceeds $34^{\circ} \mathrm{C}$, and reduced for maximum temperatures below $5^{\circ} \mathrm{C}$. Thus the coefficient relating equilibrium evaporation to potential evapotranspiration varies from 0.5 to 1.35 depending upon the maximum temperature.

Soil evaporation is a function of soil water content of the surface layer and energy reaching the soil surface, which is inversely proportional to the leaf area index and soil reflectance. Water extraction by the roots from each layer is calculated based upon the extractable soil water for a given layer, the length density of roots in that layer, and the resistance of roots to water uptake. Growth of new roots is distributed over the various soil layers as a function of a root preference factor for each layer, the amount of extractable water in each layer, and whether root progression has reached a given layer. For each layer, root senescence is also predicted as a function of plant age and extractable water. Actual water uptake from the rooting zone is the minimum of root water extraction and potential transpiration by the crop.

\subsection{Model inputs and outputs}

The model needs location, weather, soil, and management input data. Location variables are latitude and longitude (radians). Daily weather variables are solar radiation $\left(\mathrm{MJ} / \mathrm{m}^{2}\right)$, rainfall $(\mathrm{mm})$, maximum and minimum temperature $\left({ }^{\circ} \mathrm{C}\right)$. Soil data required for each soil layer are layer-thickness (DLAYER, $m$ ), saturated water content (SAT, $\mathrm{cm}^{3} / \mathrm{cm}^{3}$ ), drained upper limit of soil water content (DUL, $\mathrm{cm}^{3} / \mathrm{cm}^{3}$ ), lower limit of plant-extractable water $\left(\mathrm{LL}, \mathrm{cm}^{3} / \mathrm{cm}^{3}\right.$ ), soil bulk density (BD, $\mathrm{g} / \mathrm{cm}^{3}$ ), root distribution weighting factor (WR, unitless), and initial soil water content at start of simulation $\left(\mathrm{cm}^{3} / \mathrm{cm}^{3}\right)$. Additional soil parameters required for the whole profile are stage 1 soil evaporation coefficient ( $\mathrm{U}, \mathrm{mm}$ ), soil surface reflectance (SALB, unitless), runoff curve number ( $\mathrm{CN} 2$, unitless), whole profile drainage rate coefficient (swCON, fraction drained per day), and a growth reduction factor (PHFAC3, unitless) to account for crop growth reduc- tion caused by poor soil fertility or soil pest or disease present during the entire season. The managemen inputs are sowing date (day of year), plant populatior (plants $/ \mathrm{m}^{2}$ ), inter-row spacing $(\mathrm{m})$, sowing deptr $(\mathrm{cm})$, and amounts $(\mathrm{mm})$ and dates (day of year) $\mathrm{o}$ : irrigation applied.

In addition to the above data, the model also use: crop-specific and cultivar-specific coefficients. Culti. var-specific coefficients, given in the genetics file, ar: used to define the sensitivity of each cultivar to day. length and photothermal day threshold values for var ious growth phases. Coefficients related to number mass, and rate of growth of vegetative and reproductivi organs are also defined in this file.

The model predicts the timing of vegetative anc reproductive growth stages from emergence to physi ological maturity, daily growth of plant components leaf area index, specific leaf area, root distribution is the soil, percent nitrogen in the crop canopy, final yield yield components, and harvest index. In addition, dail! soil water balance components, namely soil evapora tion, transpiration, drainage, and surface runoff are als estimated.

\section{Materials and methods}

\subsection{Multilocation experiments}

Field experiments with groundnut were conducter from 1987 to 1992 at four locations in India ranging is latitude, longitude, and elevation. These locations pro vided a wide range of environments for testing of th model as they differed in soils, rainfall, and other ele ments of climate (Tables 2 and 3). The soil at Anan is deeper $(\approx 2.0 \mathrm{~m})$ and has a higher available wate retention capacity ( $\approx 300 \mathrm{~mm}$ ) in the rooting zone thas the other locations ( 70 to $180 \mathrm{~mm}$ ). Patancheru an Anand have more assured rainfall ( 780 to $910 \mathrm{~mm}$ and a longer growing period compared with the othe locations ( 590 to $600 \mathrm{~mm}$ ).

The cultivar Robut 33-1 was grown in experiment conducted at all locations in combination with othe management practices of local importance such as loce cultivars, plant population, sowing date, and irrigatio: management. As testing of the model PNUTGRO wa limited to the cultivar Robut 33-1 grown at optimur plant population level ( 30 to 33 plants $/ \mathrm{m}^{2}$ ), sowin 
Table 2

ioil parameters of four locations used for model validation. See text or explanation of abbreviations

\begin{tabular}{lcccc}
\hline 'arameters & Locations & & & \\
& & & & \\
& Anand & Patancheru & Anantapur Coimbatore \\
& & & & \\
joil type & Inceptisol Alfisol & Alfisol & Alfisol \\
J (mm) & 6.1 & 9.10 & 3.00 & 9.90 \\
iwcoN (fraction & 0.70 & 0.84 & 0.80 & 0.70 \\
Irained/day) & & & & \\
ZN2 (unitless) & 60.00 & 84.00 & 60.00 & 60.00 \\
'HFAC3 (unitless) & 1.00 & 1.00 & 0.77 & 0.63 \\
Zxtractable water & 307 & 118 & 70 & 175 \\
:apacity (mm) & & & & \\
\hline
\end{tabular}

lates and moisture regimes, the other treatments of the ixperiments will not be described. The experiments and he pertinent treatments against which the model was ested are given in Table 1. Plot size, crop management, and frequency of observations varied across locations and years. Plot size was $54 \mathrm{~m}^{2}$ at Anand, 27 to $144 \mathrm{~m}^{2}$ it Patancheru, 30 to $60 \mathrm{~m}^{2}$ at Anantapur, and $24 \mathrm{~m}^{2}$ at Zoimbatore. Fertilizer application in $\mathrm{kg} / \mathrm{ha}$ at sowing was $10 \mathrm{~N}$ and $25 \mathrm{P}$ at Anand; $10-20 \mathrm{~N}, 20-40 \mathrm{P}$, and $50 \mathrm{~K}$ at Patancheru; $20 \mathrm{~N}, 40 \mathrm{P}$, and $40 \mathrm{~K}$ at Anantapur; and $10 \mathrm{~N}, 20 \mathrm{P}$, and $45 \mathrm{~K}$ at Coimbatore. At Coimbatore ;wo additional levels of $\mathrm{P}$ application ( 35 and 50 ) were also included in the experiments, but the crop did not espond to these levels. In addition to basal application of fertilizers, gypsum at the rate of $500-600 \mathrm{~kg} / \mathrm{ha}$ at Patancheru and $200 \mathrm{~kg} / \mathrm{ha}$ at Coimbatore was also applied at pod-initiation stage. The crops were flood migated at all locations except at Patancheru where jerforated pipes or sprinklers were used. The amount of water applied was recorded using water flow meters or catch-cans. Crops were sprayed against diseases and jests, however, it was not always possible to achieve zomplete control of diseases and pests at all locations.

\subsection{Measurements}

\section{Crop phenology}

Both vegetative (V-stages) and reproductive stages (R-stages) were recorded as per Boote (1982). Vstages were recorded as the number of nodes formed on the main branch of the groundnut plant. The crop was considered to have reached a particular R-stage when $50 \%$ of the plants had shown that stage of devel-
Table 3

Mean maximum temperature (MAXT), mean minimum temperature (MINT), mean daylength (DL), mean solar radiation (RAD), and total rainfall (RF) during the growth phases of groundnut at various sites

$\begin{array}{llllll}\text { Growth } & \text { MAXT } & \text { MINT } & \text { DL } & \text { RAD } & \text { RF } \\ \text { phase } & \left({ }^{\circ} \mathrm{C}\right) & \left({ }^{\circ} \mathrm{C}\right) & (\mathrm{h}) & \left(\mathrm{MJ} / \mathrm{m}^{2} / \mathrm{d}\right) & (\mathrm{mm})\end{array}$

a. Anand (Lat. $22^{\circ} 35^{\prime} \mathrm{N}$; Long. $72^{\circ} 55^{\prime} \mathrm{E}$; Elev. $48 \mathrm{~m}$ )

Rainy season 1988

$\begin{array}{cccccc}\begin{array}{c}\text { Sowing- } \\ \text { Flowering }\end{array} & 31.4 & 25.5 & 13.2 & 12.2 & 496 \\ \begin{array}{c}\text { Flowering- } \\ \text { Full pod }\end{array} & 31.0 & 25.3 & 12.7 & 9.4 & 223 \\ \begin{array}{c}\text { Full pod- } \\ \text { Maturity }\end{array} & 33.8 & 23.8 & 11.9 & 15.5 & 237 \\ \text {. } & & & & & \end{array}$

b. Patancheru (Lat. 17³2' N; Long. $7^{\circ} 16^{\prime}$ E; Elev. $545 \mathrm{~m}$ )

Rainy season 1987

\begin{tabular}{|c|c|c|c|c|c|}
\hline $\begin{array}{l}\text { Sowing- } \\
\text { Flowering }\end{array}$ & 31.5 & 23.3 & 12.9 & 17.4 & 27 \\
\hline $\begin{array}{l}\text { Flowering- } \\
\text { Full pod }\end{array}$ & 29.1 & 22.4 & 12.5 & 14.2 & 85 \\
\hline $\begin{array}{l}\text { Full pod- } \\
\text { Maturity }\end{array}$ & 31.1 & 21.1 & 11.8 & 17.4 & 210 \\
\hline \multicolumn{6}{|c|}{ Rainy season 1990} \\
\hline $\begin{array}{l}\text { Sowing- } \\
\text { Flowering }\end{array}$ & 30.9 & 22.7 & 13.0 & 16.3 & 99 \\
\hline $\begin{array}{c}\text { Flowering- } \\
\text { Full pod }\end{array}$ & 29.8 & 22.1 & 12.8 & 16.3 & 202 \\
\hline $\begin{array}{l}\text { Full pod- } \\
\text { Maturity }\end{array}$ & 29.0 & 21.8 & 12.1 & 15.2 & 278 \\
\hline \multicolumn{6}{|c|}{ Post-rainy season 1991} \\
\hline $\begin{array}{l}\text { Sowing- } \\
\text { Flowering }\end{array}$ & 27.9 & 12.1 & 11.0 & 17.0 & 0 \\
\hline $\begin{array}{l}\text { Flowering- } \\
\text { Full pod }\end{array}$ & 31.3 & 14.6 & 11.4 & 19.9 & 0 \\
\hline $\begin{array}{l}\text { Full pod- } \\
\text { Maturity }\end{array}$ & 37.5 & 21.2 & 12.3 & 22.2 & 19 \\
\hline \multicolumn{6}{|c|}{ c. Anantapur (Lat. $14^{\circ} 41^{\prime} \mathrm{N}$; Long. $77^{\circ} 40^{\prime} \mathrm{E}$; Elev. $350 \mathrm{~m}$ ) } \\
\hline \multicolumn{6}{|c|}{ Rainy season 1989} \\
\hline $\begin{array}{l}\text { Sowing- } \\
\text { Flowering }\end{array}$ & 32.2 & 22.4 & 12.7 & 16.6 & 362 \\
\hline $\begin{array}{l}\text { Flowering- } \\
\text { Full pod }\end{array}$ & 34.9 & 25.0 & 12.3 & 17.4 & 74 \\
\hline $\begin{array}{l}\text { Full pod- } \\
\text { Maturity }\end{array}$ & 32.9 & 21.5 & 11.7 & 19.2 & 166 \\
\hline \multicolumn{6}{|c|}{ d. Colmbatore (Lat. $11^{\circ} \mathrm{OO}$ 'N; Long. $77^{\circ} 00^{\circ} \mathrm{E}$; Elev. $427 \mathrm{~m}$ ) } \\
\hline \multicolumn{6}{|c|}{ Post-rainy season 1990} \\
\hline $\begin{array}{l}\text { Sowing- } \\
\text { Flowering }\end{array}$ & 31.7 & 16.2 & 11.5 & 16.5 & 0 \\
\hline $\begin{array}{l}\text { Flowering- } \\
\text { Full pod }\end{array}$ & 34.8 & 19.8 & 11.8 & 18.1 & 42 \\
\hline $\begin{array}{l}\text { Full pod- } \\
\text { Maturity }\end{array}$ & 35.2 & 23.2 & 12.2 & 21.3 & 130 \\
\hline
\end{tabular}


opment. Phenological observations were taken on at least 5 plants per plot at all locations. Plants were observed every two days at Patancheru and approximately at weekly intervals at other locations.

\section{Growth analysis}

Frequency of plant sampling and sample size for growth analysis varied across locations. Samples were taken at 7- to 10-day intervals at Patancheru and 6 to 7 times during the season at other locations. Area sampled from each plot ranged from 0.6 to $0.75 \mathrm{~m}^{2}$ at Patancheru, $0.2 \mathrm{~m}^{2}$ at Anand, 0.3 to $0.6 \mathrm{~m}^{2}$ at Anantapur, and $0.3 \mathrm{~m}^{2}$ at Coimbatore. The number of replications sampled was at least two at each location, except Anantapur where only one replication was sampled. Total number of plants sampled varied with the harvested area. From this large sample, a sub-sample of 3-5 plants was taken to determine leaf area and partition of dry matter to various plant organs such as leaves, stems, shells, pods, and seeds. To determine dry weights, the sub-sample plant components and the remaining part of each large sample were oven dried at $60^{\circ} \mathrm{C}$ for 3 to 4 days and weighed. At locations where the harvest area for plant sampling was less than 0.3 $\mathrm{m}^{2}$, no sub-samples were taken and the whole sample was used for growth analysis.

\section{Soil moisture}

At Patancheru soil moisture was recorded at weekly intervals using a neutron probe. At least one access tube was installed in each plot and probe observations were taken at $15-\mathrm{cm}$ depth intervals starting at $30 \mathrm{~cm}$ soil depth to $120 \mathrm{~cm}$. Soil moisture in the $0-10$ and 10 $22.5 \mathrm{~cm}$ layers, and at the other locations, was determined by the gravimetric method. The depths of soil sampling and the frequency of observations varied across locations.

\section{Final yields}

Total dry matter, pod, and seed yields were recorded in all replications of the experiments at each site and the area harvested was variable across sites and years, ranging from $5.0 \mathrm{~m}^{2}$ to $30 \mathrm{~m}^{2}$. Dry weights of haulms, pods and seed were determined by oven-drying either the whole harvest of each plot or the sub-samples of the harvests. Drying procedure was the same as for growth analysis.

\section{Weather data}

All the daily weather data required for model input were obtained from the meteorological observatory located within $1.5 \mathrm{~km}$ of the experimental site at each location.

All data on climate, crop and soil collected over years were entered in the computer using the database management program of the Decision Support System for Agrotechnology Transfer (DSSAT) (IBSNAT, 1989) and retrieved to create files required for model execution.

\subsection{Model calibration}

Genetic coefficients and soil parameters of the mode] were set by calibration against the data obtained from the initial experiments (Table 1) and these were fixec when the model was validated using the independen data obtained during the later years. Steps followed for calibration of soil parameters and genetic coefficient: are described below:

\section{Calibration of soil parameters}

Soil survey data on mechanical composition anc associated parameters were collected for each locatior to create the file (SPROFILE.PN2) containing the soil input data required to execute the model (see sectior 2.4). This file was created using the soils-data-retrieva program of the Decision Support System for Agrotech. nology Transfer (DSSAT) (IBSNAT, 1989). Because the input data used to create file SPROFILE.PN2 did no pertain to the individual fields where the experiment: were conducted, the parameters thus generated by the retrieval program required adjustment. This was done as follows:

i. Modifications were made in the upper (DUL) anc lower limits (LL) of soil water availability suck that the simulated and observed limits of wates availability matched during both wetting and dry. ing cycles. These adjustments were made first for the top layers and then for the sub-soil layers.

ii. If the simulated water content in the sub-soil layer: was underestimated, the runoff curve number was reduced and the drainage coefficient increased (i) water was accumulated above DUL in the top lay. ers) to percolate more water into sub-soil layers If the soil water contents were overestimated, the curve number was increased to increase runoff anc 
the drainage coefficient decreased to decrease infiltration and to slow down the drainage of water.

The rate of water loss from the top layer (evaporation layer) was matched with the observed data by adjusting the upper limit of the stage-I evaporation $(\mathrm{U})$. Increasing the value of $\mathrm{U}$ increased the rate of water loss and vice-versa.

To match the rates of water loss in the rooting zone with the observed changes in soil water, changes were made in the rooting coefficients (WR) representing relative rooting density in various layers. As a principle, roots have exponential decline in root length density with soil depth. Root coefficients in the soil vary from zero to 1 depending upon the root density in a soil layer. As a rule, the root density coefficients for the top 30 to $45 \mathrm{~cm}$ (first 2-3 layers) should equal 1.0 and then decrease exponentially with depth. Rates of water depletion from the rooting zone were adjusted by adapting the value of root coefficients while main-
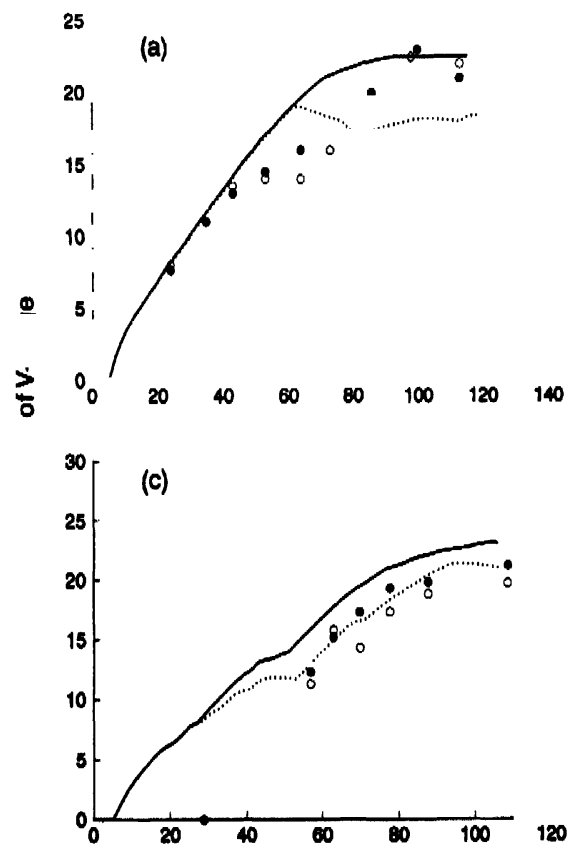

taining their exponential decline with depth. Increasing the value increased water depletion and vice-versa.

v. The above stepwise adjustment in soil coefficients was repeated several times until the observed soil water changes matched the simulated soil water changes.

In addition to the above soil physical parameters, the factor PHFAC3, which is an index of overall soil fertility of a location including the influence of soil diseases and pests on crop growth rate, was also determined for each location against the total biomass production data from adequately watered treatments of the calibration experiments. Changes were made in PHFAC3 so that the simulated biomass production matched the actual amount of biomass produced at different times during the season. The value of PHFAC3 once determined for a location was fixed for future predictions. The calibration results of soil parameters are given in Table 2.

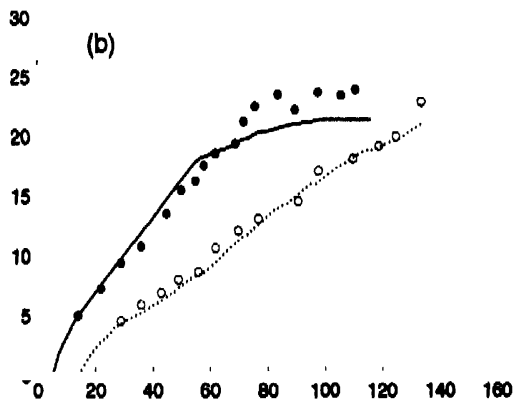

(d)

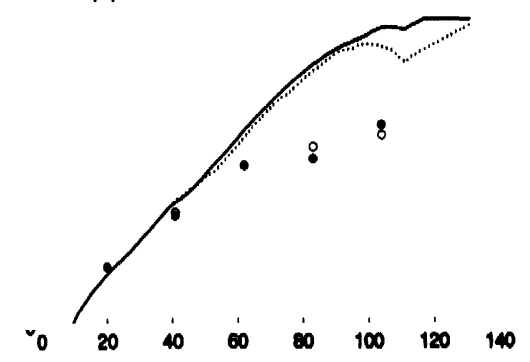

Days After Sowing

1. Simulated (lines) and observed (data points) progression of $V$-stages at (a) Patancheru in the irrigated ( $O$, solid line) and rainfed $(O$, en line) treatments during the 1987 rainy season; at (b) Patancheru in the 1990 rainy (O, solid line) and 1991 post-rainy $(O$, broken line) ons; at (c) Anantapur in the irrigated (O, solid line) and rainfed ( $O$, broken line) treatments during the 1989 rainy season, and (d) at abatore in the irrigated $(\Theta$, solid line) and partially irrigated $(O$, broken line) treatments during the 1990 post-rainy season. 


\section{Calibration of genetic coefficients}

As cvs. Robut 33-1 and TMV 2 are not normally grown outside India, their genetic coefficients were not available. To determine these coefficients, we adjusted the genetic coefficients of $c v$. Florunner, earlier determined by Boote et al. (1987), to match the growth and development data of Robut 33-1 and TMV 2. Calibration of Robut 33-1 was done against the data obtained from the nonstressed and well fertilized treatments of the calibration experiments (Table 1). As cultivar TMV 2 was sown along with Robut 33-1 in experiments conducted during the 1987 post-rainy season at Patancheru and 1987 rainy season at Anantapur, the calibration of TMV 2 was done using data of these two years. Genetic coefficients of these cultivars were estimated by following the procedure as described by Boote et al. (1989).

\subsection{Model validation}

To test the calibrated model, independent data sets were available from the rainy and post-rainy season experiments conducted at the four locations (Table 1). Data for validation came from the treatments in which
Robut 33-1 was grown at recommended fertilizer level and at moisture regimes ranging from rainfed to adequate irrigation. Plant population in those treatments ranged from 30 to 33 plants $/ \mathrm{m}^{2}$. Crops were sprayed against diseases and pests, however, complete control was never possible.

In addition to the above validation exercise, we also tested the performance of the model against the long term pod yield data of groundnut cultivar TMV 2 available from the Andhra Pradesh Agricultural University Research Station at Anantapur. These data pertained tc the rainfed treatments of the experiments conductec during 1979 to 1990 . Using the historical weather datz for Anantapur and the PNUTGRO model, yields of TMV 2 were simulated for the rainfed situation. Dates of sowing were considered the same as those of the fielc experiments. Plant population ( 33 plants $/ \mathrm{m}^{2}$ ), fertil. izer application, and plant protection were considerec optimal.

\section{Results and discussion}

The capability of the model to predict growth anc development of groundnut (cv. Robut 33-1) was
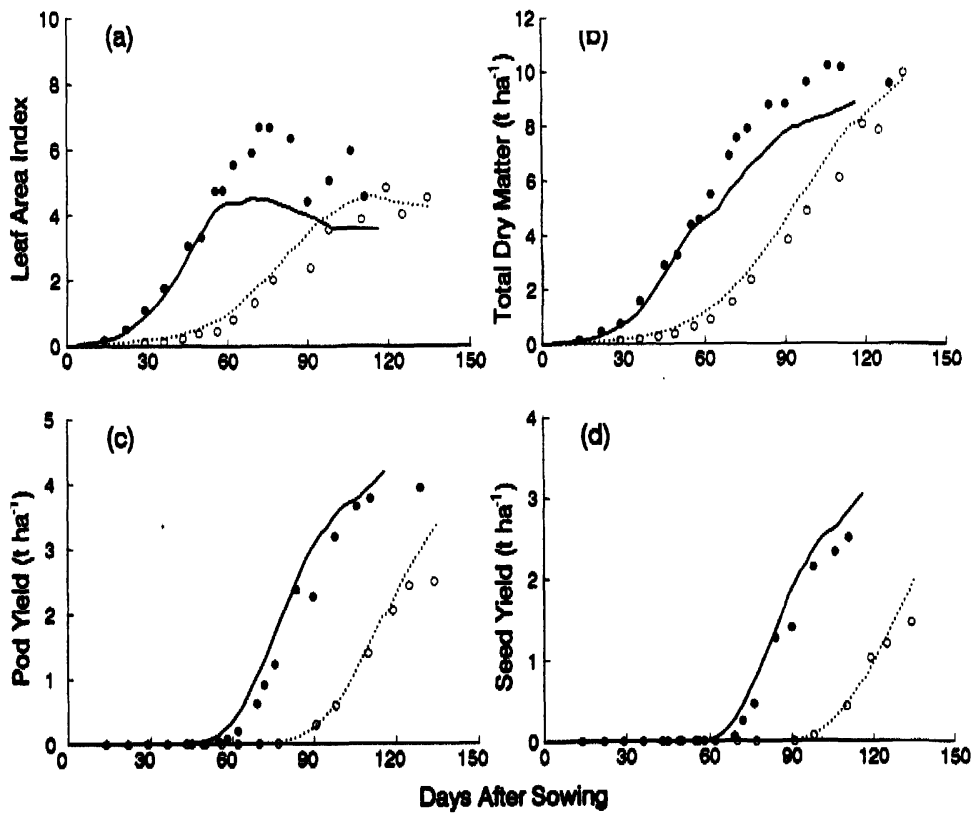

Fig. 2. Simulated (lines) and observed (data points) values of (a) leaf area index, (b) total dry matter production, (c) pod yield, and (d) seec yield of groundnut during the 1990 rainy (, solid line) and 1991 post-rainy $(O$, broken line) seasons at Patancheru. 
Table 4

Simulated (S) and simulated minus observed $(S-O)$ days after sowing to flowering, pod-initiation, full-pod and physiological maturity of groundnut cv. Robut 33-1 at four locations in various experiments. See Table 1 for explanation of abbreviations

\begin{tabular}{|c|c|c|c|c|c|c|c|c|c|c|}
\hline \multirow[t]{2}{*}{ Season } & \multirow[t]{2}{*}{ Sowing date } & \multirow[t]{2}{*}{ Moisture regimes } & \multicolumn{2}{|c|}{ Flowering } & \multicolumn{2}{|c|}{ Pod-initiation } & \multicolumn{2}{|c|}{ Full-pod } & \multicolumn{2}{|c|}{ Physiological maturity } \\
\hline & & & s & $s-0$ & $\mathrm{~S}$ & $s-0$ & S & $s-0$ & $\mathbf{S}$ & $s-0$ \\
\hline \multicolumn{11}{|l|}{ Anand } \\
\hline \multirow[t]{2}{*}{ R 1988} & $04 \mathrm{Jul}$ & $\mathrm{RF}$ & 28 & 2 & 43 & -5 & 54 & -8 & 119 & -14 \\
\hline & & IR & 28 & 2 & 43 & -5 & 54 & -8 & 119 & -14 \\
\hline \multicolumn{2}{|c|}{ Root mean square error $( \pm)$} & & & 2 & & 4 & 5 & 8 & & 14 \\
\hline \multicolumn{11}{|c|}{ Patancheru } \\
\hline R 1984 & $09 \mathrm{Jul}$ & RF & 29 & -3 & 44 & - & 79 & -14 & 118 & 7 \\
\hline \multirow{2}{*}{ R 1987} & $13 \mathrm{Jul}$ & $\mathrm{RF}$ & 28 & 0 & 43 & - & 53 & 2 & 117 & -2 \\
\hline & & IR & 28 & -2 & 43 & - & 53 & - & 117 & 2 \\
\hline R 1990 & 19 Jun & IR & 29 & 1 & 45 & -3 & 55 & -2 & 116 & -13 \\
\hline PR 1990 & 04 Jun & IR & 44 & -3 & 64 & -4 & 75 & 2 & 145 & 29 \\
\hline PR 1991 & $04 \mathrm{Dec}$ & IR & 55 & 3 & 76 & -4 & 90 & 2 & 135 & 0 \\
\hline R 1992 & $27 \mathrm{Jun}$ & IR & 29 & 1 & 44 & 2 & 54 & 4 & 135 & 0 \\
\hline \multicolumn{3}{|c|}{ Root mean square error $( \pm)$} & & 2.2 & & 3.3 & & 6.9 & & 12.3 \\
\hline \multicolumn{11}{|c|}{ Anantapur } \\
\hline \multirow[t]{4}{*}{ R 1988} & $12 \mathrm{Jul}$ & RF & 30 & 0 & 45 & -5 & 55 & 0 & - & - \\
\hline & & IR & 30 & 0 & 45 & -5 & 55 & 0 & - & - \\
\hline & 12 Aug & RF & 28 & 6 & 44 & -7 & 54 & -2 & 120 & - \\
\hline & & IR & 28 & 5 & 44 & -6 & 54 & -2 & 120 & - \\
\hline \multirow[t]{2}{*}{ R 1989} & $11 \mathrm{Jul}$ & $\mathrm{RF}$ & 30 & -15 & 60 & -1 & 73 & 1 & 120 & 13 \\
\hline & & IR & 30 & -13 & 52 & -3 & 62 & -7 & 120 & 14 \\
\hline \multirow[t]{4}{*}{ R 1990} & 16 Jun & $\mathrm{RF}$ & 29 & -2 & 61 & 5 & - & - & - & - \\
\hline & & IR & 29 & -2 & 47 & -5 & 58 & 3 & 118 & 7 \\
\hline & 04 Aug & $\mathrm{RF}$ & 29 & -2 & 60 & 9 & 72 & 14 & 118 & 1 \\
\hline & & IR & 29 & - & 46 & -3 & 60 & 3 & 117 & 5 \\
\hline \multicolumn{3}{|c|}{ Root mean square error $( \pm)$} & & 7.2 & & 5.3 & & 6.1 & & 10.0 \\
\hline \multicolumn{11}{|c|}{ Coimbatore } \\
\hline \multirow[t]{2}{*}{ R 1989} & $04 \mathrm{Jul}$ & PIR & 28 & 7 & 44 & -5 & 55 & -10 & 116 & 14 \\
\hline & & IR & 28 & 6 & 44 & -6 & 54 & -7 & 116 & 14 \\
\hline \multirow[t]{2}{*}{ PR 1990} & 11 Jan & PIR & 37 & - & 58 & 8 & 68 & -2 & 131 & - \\
\hline & & IR & 37 & - & 55 & 4 & 66 & -6 & 131 & - \\
\hline \multicolumn{2}{|c|}{ Root mean square error $( \pm)$} & & & 6.5 & & 5.9 & & 6.9 & & 14.0 \\
\hline
\end{tabular}

assessed in terms of its ability to predict crop response as influenced by sowing date, season, rainfall, and irrigation. Data from the experiments conducted during 1988 rainy season at Anand, 1987 and 1990 rainy seasons at Patancheru, 1991 post-rainy season at Patancheru, 1989 rainy season at Anantapur, and 1990 post-rainy season at Coimbatore were available (Table 1) to illustrate the influence of management factors on phenology and growth processes of groundnut. Various processes considered were vegetative and reproductive development, growth of plant organs, soil moisture changes in the rooting zone, and yields at harvest. The above six seasons varied in different elements of weather. The locations differed in maximum and minimum temperatures during the seasons (Table 3). In addition, the locations differed markedly in the amount of rainfall received during different growth phases. Day length was slightly longer at Anand and Patancheru during the rainy seasons compared with the other two sites or seasons. Crop response in these environments is discussed below. 
Table 5

Simulated $(\mathbf{S})$ and observed $(0)$ total dry matter production, pod yield, and seed yield of groundnut in various seasons, sowing dates and moisture regimes at four locations. See table 1 for explanation of abbreviations

\begin{tabular}{lllll}
\hline Season Sowing date & Moisture regime & Total dry matter $(t / h a)$ & Pod yield $(t / h a)$ & Seed yield ( $t / h a)$
\end{tabular}

0

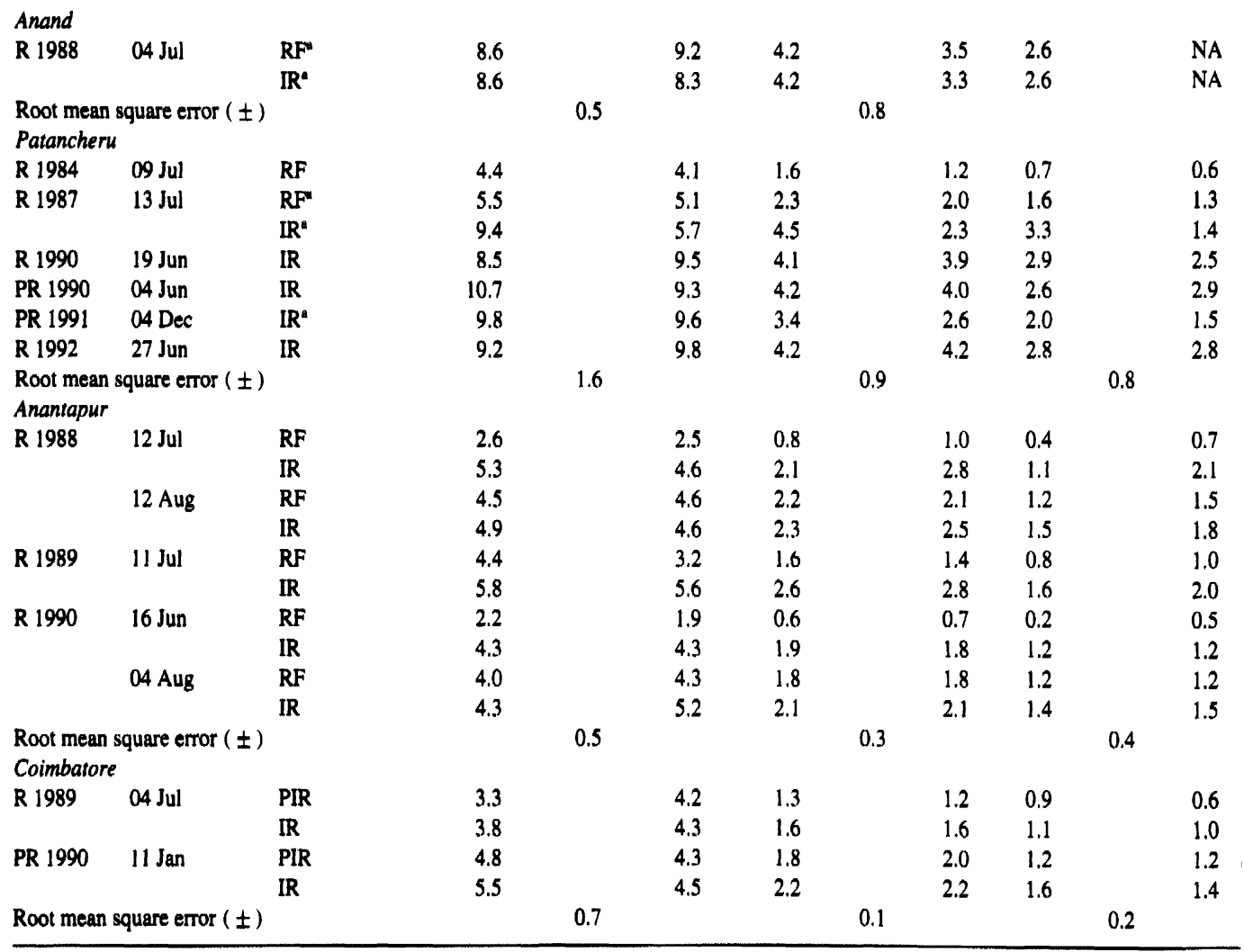

"Crop growth affected by late leaf spot or rust disease; NA $=$ Data not recorded.

\subsection{Vegetative development}

The model predicted the progression of vegetative stages (V-stages) accurately during both the 1990 rainy and 1991 post-rainy season at Patancheru except later during the rainy season when the model underestimated V-stage progression (Fig. 1b). This is attributed to the early prediction of pod and seed growth by the model for the rainy season which retarded the Vstage progression (Fig. 2). Low temperatures at Patancheru during the post-rainy season delayed vegetative development. The rate of development predicted by the model was, however, similar to the observed data. Moisture stress delayed vegetative development at Anantapur in the rainfed treatment compared to the irrigated treatment (Fig. 1c). Although the model overestimated V-stages in both treatments, the effect of water stress was accurately predicted by the model. The model also predicted V. stages accurately both at Patancheru during the 1987 rainy season and at Coimbatore during the early phase of crop growth (Fig. 1a and 1d). After 50 days of sowing (DAS) at Patancheru, the influence of diseases and pests masked the effect of water stress on the observed V-stage progression. However, the model predicted the influence of water deficit on V-stage 


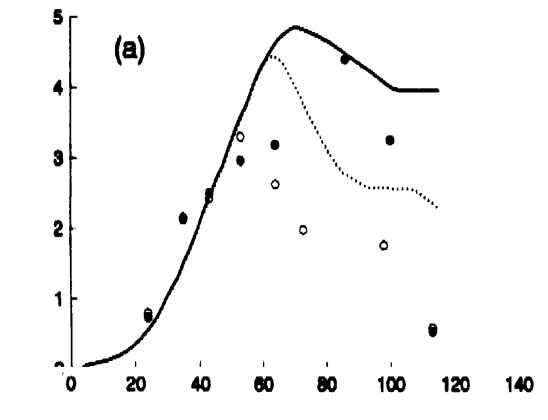

10r
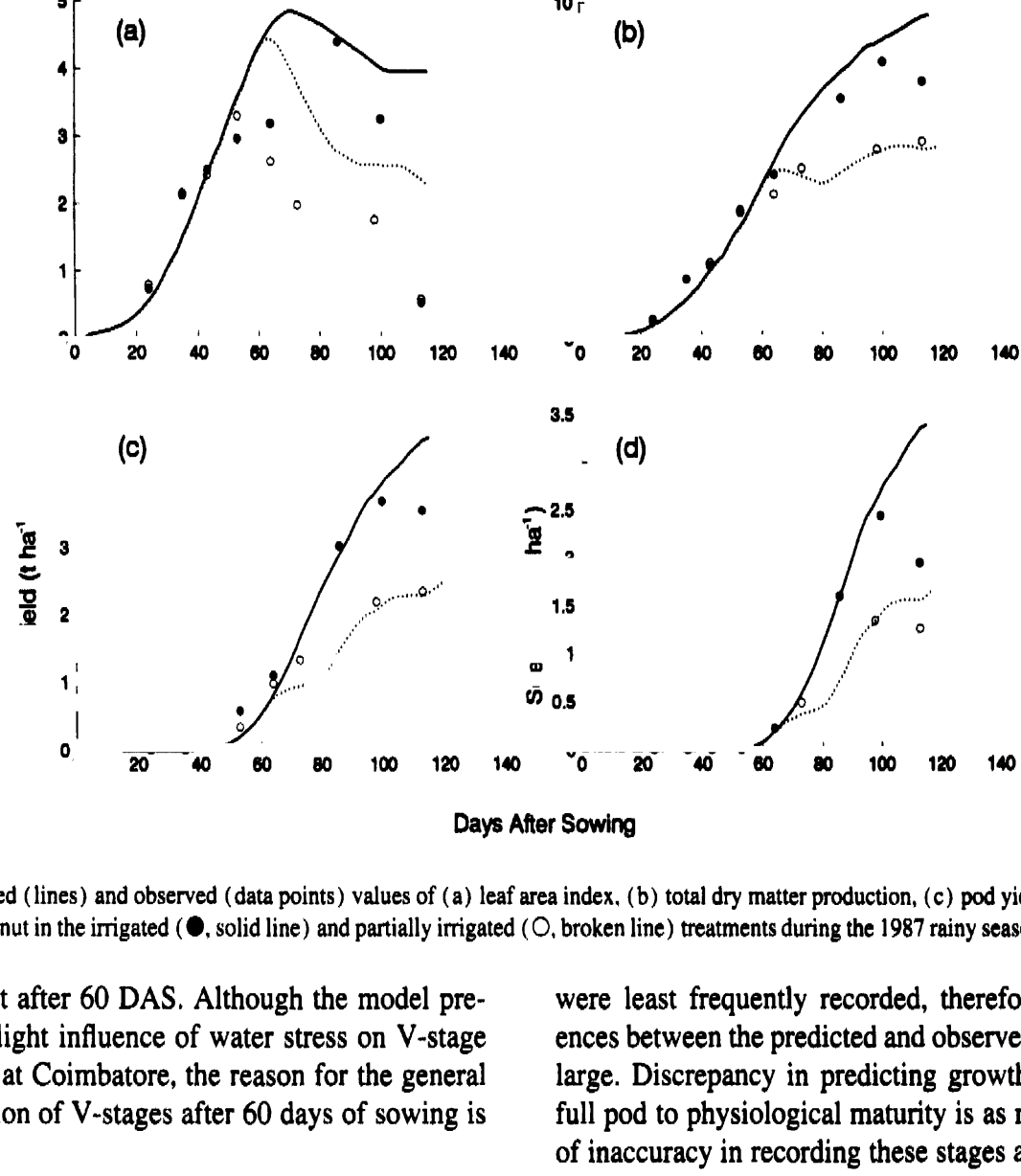

3.5
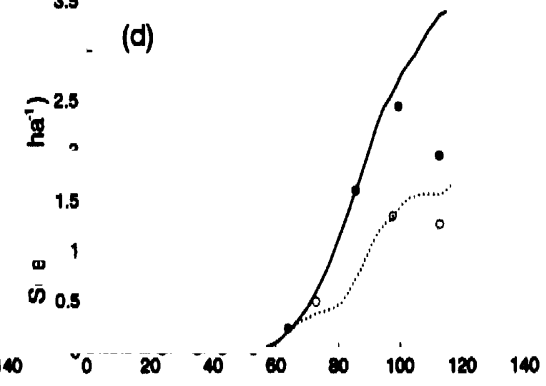

Days After Sowing

Fig. 3. Simulated (lines) and observed (data points) values of (a) leaf area index. (b) total dry matter production, (c) pod yield, and (d) seed yield of groundnut in the irrigated (, , solid line) and partially irrigated $(O$, broken line) treatments during the 1987 rainy season at Patancheru.

development after 60 DAS. Although the model predicted the slight influence of water stress on V-stage progression at Coimbatore, the reason for the general overestimation of $\mathrm{V}$-stages after 60 days of sowing is not clear.

\subsection{Reproductive development}

Growth stages were recorded with greater frequency at Patancheru than at other locations and this gave better agreement between predicted and observed timing of reproductive growth stages (Table 4). At Patancheru, flowering and pod-initiation were predicted within \pm 5 days across seasons. Low temperatures during the 1990 and 1991 post-rainy seasons at Patancheru significantly delayed the appearance of flowering and pod-initiation. These stages were predicted within \pm 4 days by the model. At Anand flowering and pod-initiation were predicted within \pm 5 days. Predictions of various growth stages at Anantapur were fairly accurate, except for the 1989 rainy season when the prediction of flowering was too early. At Coimbatore the growth stages were least frequently recorded, therefore the differences between the predicted and observed values were large. Discrepancy in predicting growth stages from full pod to physiological maturity is as much because of inaccuracy in recording these stages as of deficiencies in the model. This is because the groundnut crop is indeterminate in nature and the plants have to be uprooted to record these stages accurately.

\subsection{Canopy development and growth of plant organs}

\section{Influence of season}

Growth data collected during the rainy and postrainy seasons at Patancheru were used to illustrate the model performance across seasons (Fig. 2). During the 1990 rainy season the model predicted canopy development accurately up to leaf area index (LAI) of 4.0. Beyond this value the model underestimated LAI that reached a maximum of 6.7, while the model predicted a maximum of 4.5. This discrepancy is attributed to early prediction of pod and seed growth (Figs. $2 c$ and 2d) which caused more assimilates to be partitioned to 

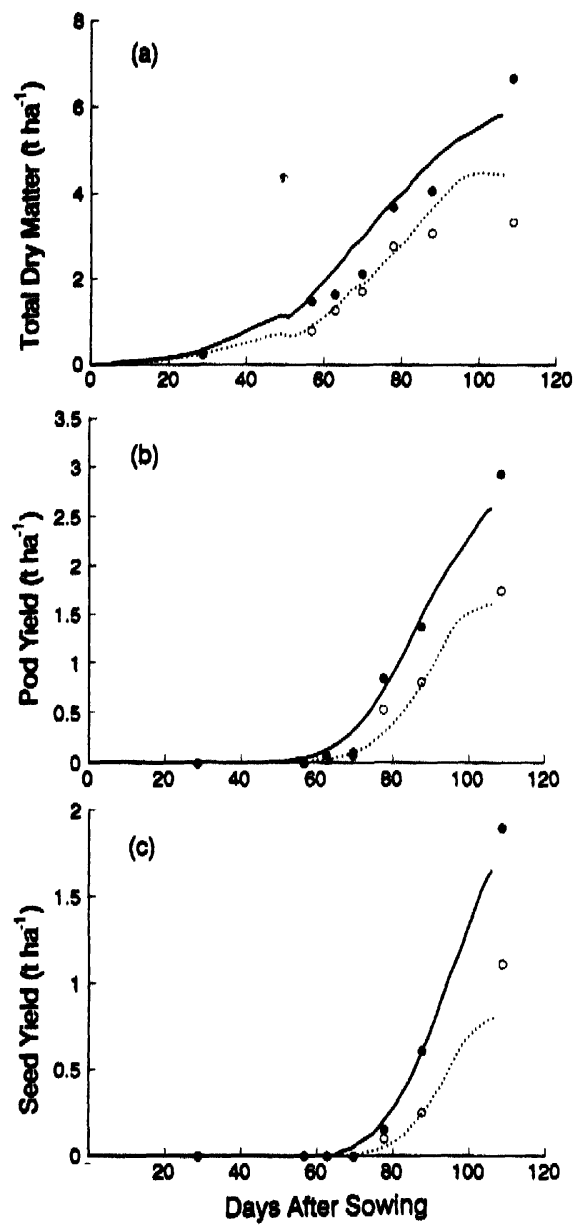

ig. 4. Simulated (lines) and observed (data points) values of (a) ital dry matter production, (b) pod yield, and (c) seed yield in the rigated ( $O$, solid line) and rainfed $(0$, broken line) treatments uring the 1989 rainy season at Anantapur.

le reproductive organs. Further translocation of assimates from shoot to the reproductive organs caused leaf enescence and decreased photosynthetic efficiency of saves, and therefore decreased the predicted rate of stal dry matter production (TDM) after 60 DAS. The bserved delay in pod growth compared to the preicted data could be because of soil factors that inhibit eg penetration and pod growth, which are not suffiiently accounted for in the model. During the 1991 ost-rainy season canopy development was slow ecause of low temperatures during the initial phase of rop growth. The model predicted the slow increase in
LAI accurately throughout the season, however, with a slight overestimation in the initial phase of crop growth. Although the model takes in to account the low temperature effects on SLA, this small overestimation may be attributed to microclimatic factors not considered in the model. Apart from the discrepancy in the estimation of TDM yields, the model predicted the pod and seed growth accurately at various times during the rainy and post-rainy seasons, except at maturity during the post-rainy season the model overestimated the yields by about $30 \%$ because of disease-induced loss of pods (Figs. 2c, 2d, and Table 5).
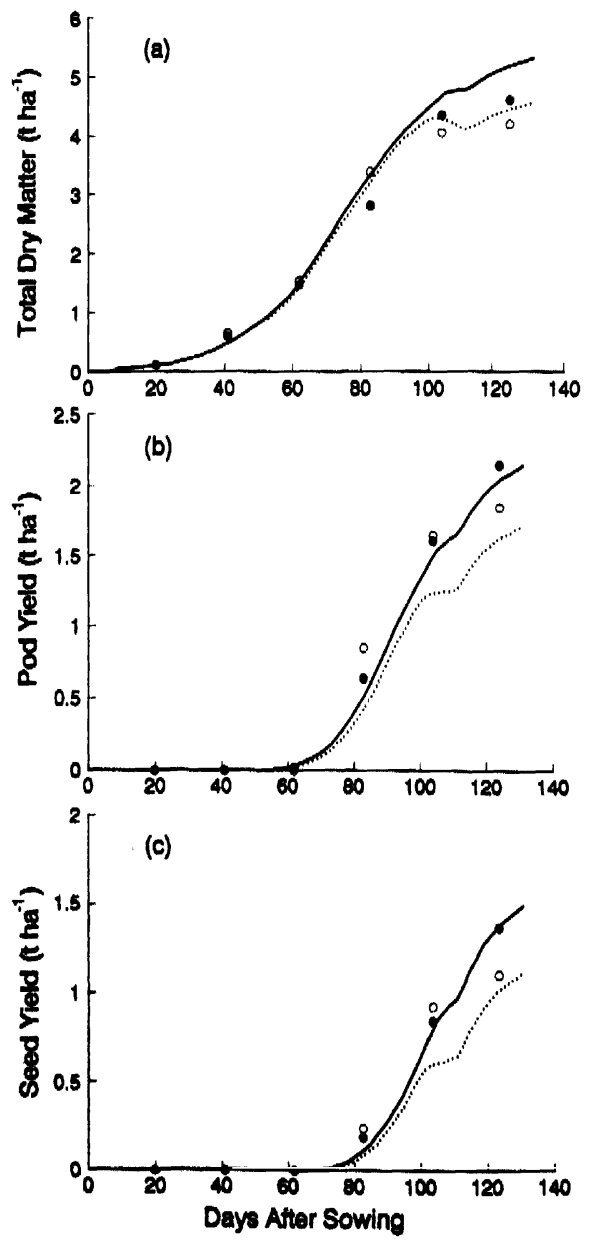

Fig. 5. Simulated (lines) and observed (data points) values of (a) total dry matter production, (b) pod yield, and (c) seed yield in the irrigated $(O$, solid line $)$ and the partially irrigated $(0$, broken line $)$ treatments during the 1990 post-rainy season at Coimbatore. 

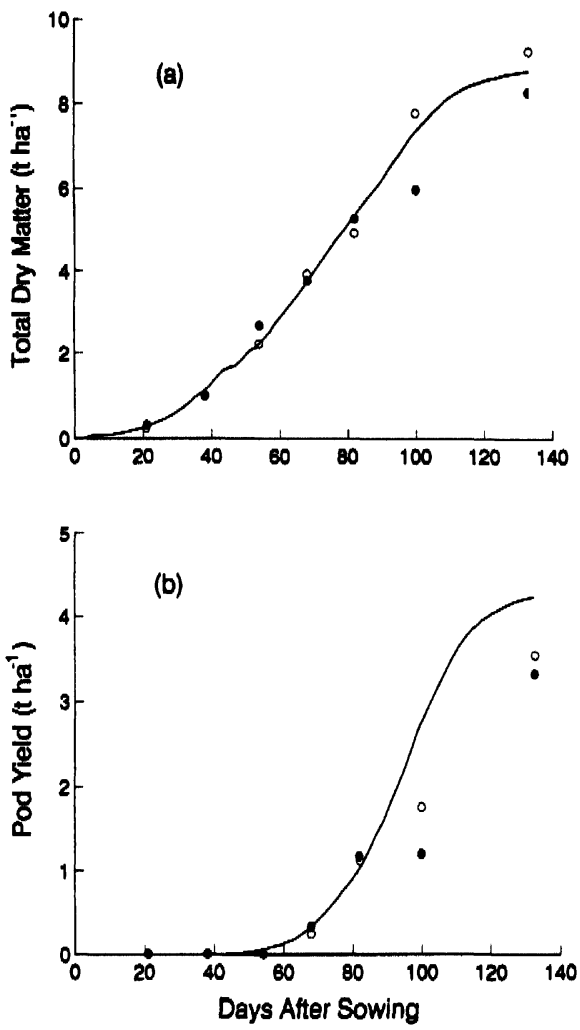

ig. 6. Simulated (lines) and observed (data points) values of (a) otal dry matter production, and (b) pod yield in the irrigated ( $O$. olid line) and the rainfed $(O$, broken line) treatments during the 988 rainy season at Anand. Simulated values for irrigated and rain'ed treatments are overlapping.

\section{'nfluence of moisture availability}

To test the model for groundnut response to moisture Ivailability, the data sets obtained from experiments :onducted during 1987 rainy season at Patancheru, 1989 rainy season at Anantapur, 1990 post-rainy season It Coimbatore and 1988 rainy season at Anand were ;onsidered. Influence of moisture stress caused by diferential irrigation was greater at Patancheru and Ananapur than at Coimbatore (Figs. 3-6). In the irrigated reatment at Patancheru, the model predicted the pattern of canopy leaf area development, total dry matter proluction, pod and seed growth close to the observed ralues except during the later part of crop growth when he crop suffered from late leaf spot disease resulting $n$ over prediction of all characteristics (Fig. 3). In fact, he decline in harvestable pod and seed yield in the rigated treatment was caused by disease-induced pod losses. Since moisture stress was the dominating factor influencing crop growth in the partially irrigated treatment at Patancheru, the patterns of dry matter production, pod and seed growth were close to the observed values in spite of overestimation of LAI during the later part of crop growth. At Anantapur, severe moisture stress occurred during the early part of crop growth despite a single storm of $362 \mathrm{~mm}$ just after sowing. Predictions of total dry matter, pod and seed yields were close to the observed values in both treatments (Fig. 4). At Coimbatore water stress occurred during the later part of the pod-filling period (Fig. 5). The model

0.25

(a)

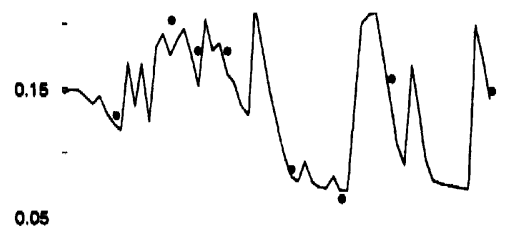

$0.3 \quad$ (b)
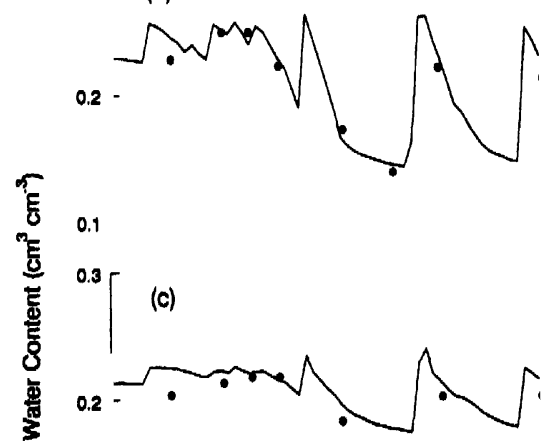

0.1

0.3

(d)

0.2

$\begin{array}{llccc}0.1 & 50 & 75 & 100 & 125 \\ & & & \\ & & & \end{array}$

Fig. 7. Simulated (lines) and observed (data points) changes in soil moisture in the (a) 0-18 cm, (b) $18-36 \mathrm{~cm}$ (c) $36-58 \mathrm{~cm}$, and (d) $58-91 \mathrm{~cm}$ soil layers under the rainfed treatment of the 1987 rainy season experiment at Patancheru. 


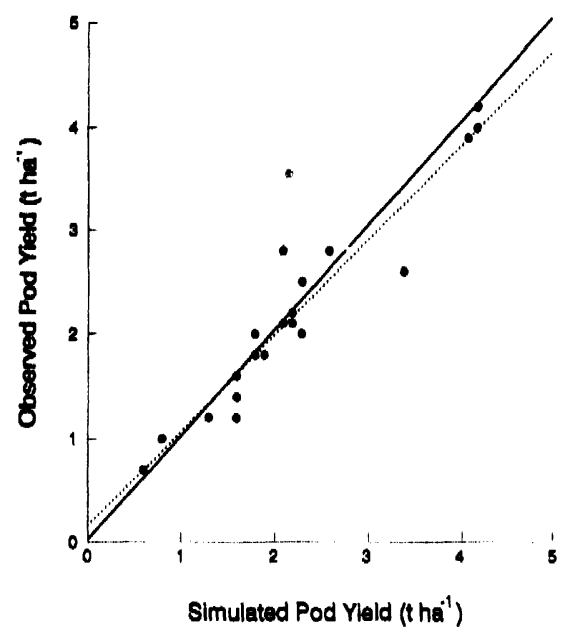

Fig. 8. Relationship between observed and simulated pod yield $\left[y=0.15( \pm 0.159)+0.91( \pm 0.065) x, r^{2}=0.90\right.$, rse $\left.=0.290\right]$ across locations. Analysis done on the pooled data. Broken line, regression line; solid line, 1:1 line.

accurately predicted the influence of water availability on total dry matter, pod and seed yields in the two irrigation treatments. At Anand only one irrigation, given during the early part of crop growth (DAS 36), was followed by high rainfall during the season (Fig. 6 and Table 1). Model predictions for total dry matter and pod yields were identical for the irrigated and rain- fed treatments. Predicted total dry matter production closely followed the observed data of the rainfed treatment. Because the actual crop yields were reduced by the incidence of late leaf spot disease during the season, the modelled yields exceeded the observed data for the irrigated treatment. It may be concluded from these results that, in the absence of diseases and pests, the model is capable of predicting the effect of water availability on crop growth and development in different environments.

\subsection{Soil moisture dynamics}

Soil moisture data collected from the rainfed treatment of the 1987 rainy season experiment were used to illustrate the performance of the model to simulate soil moisture changes in the rooting zone of groundnut. The results in Fig. 7 show that the model is able to simulate soil moisture dynamics accurately for all the layers of the rooting zone. It is inferred from this analysis that the model is capable of accurately predicting root penetration, water uptake and onset of water stress, if any, during the crop growth period.

\subsection{Final yields}

During the 1988 rainy season at Anand and during the 1987 rainy and 1991 post-rainy seasons at Patanch-

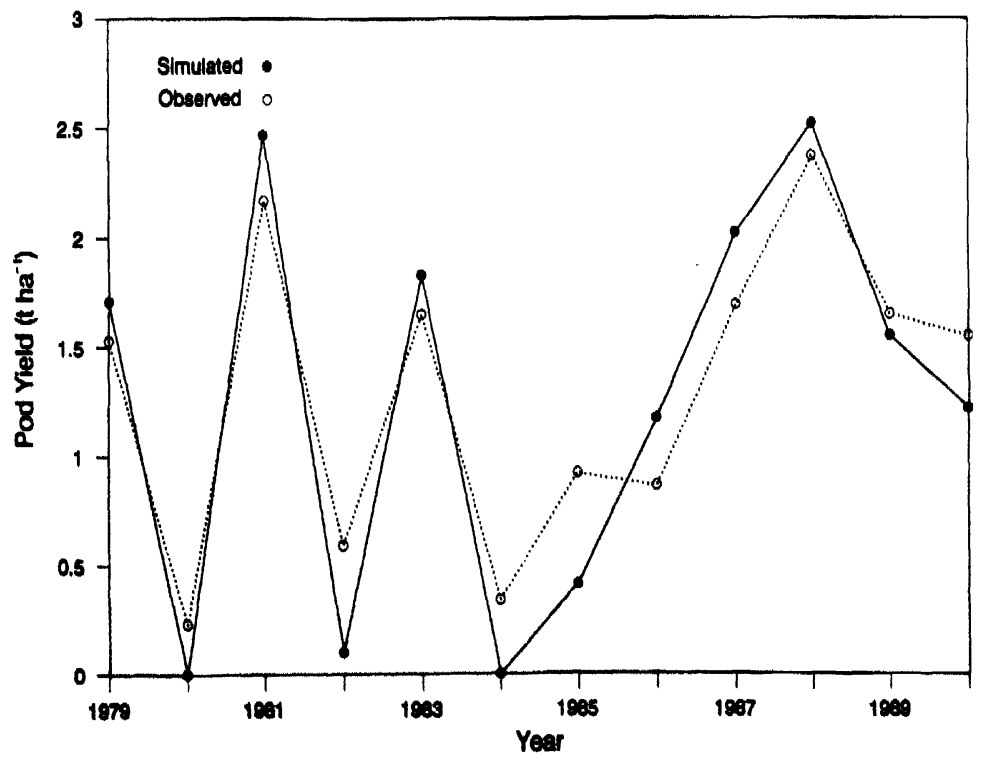

Fig. 9. Simulated (O) and observed (O) pod yields of rainfed groundnut (cv. TMV 2) grown at Anantapur during the 1979 to 1990 rainy seasons. 
, the crops were affected by late leaf spot or rust ing the later phases of crop growth. This resulted in ficantly lower pod yields than the simulated yields the irrigated treatments (Table 5). However, the ulated pod yields for the rainfed treatment were lose to the observed yields as water stress was the minating factor in that treatment rather than disease. 'or other seasons and moisture regimes, the simulated elds (TDM, pod, and seed) were within $15 \%$ of the ed values for most of the seasons and treatments it Patancheru, Anantapur, and Coimbatore.

Observed pod yield data from all four locations were led for correlation with the model predictions. As e model does not incorporate the influence of diseases Ind pests, the experiments or treatments in which the nfluence of diseases and pests was severe were :xcluded from this analysis. Simulated pod yield was ignificantly correlated $\left(r^{2}=0.90\right)$ with the observed /alues (Fig. 8). The slope of the regression line was ot significantly different from 1.0 and intercept not ignificantly different from zero. This meant that prelicted pod yields were not significantly different from sbserved yields. Considering the variation in treatnents and the range in environments in which groundlut was grown, it is concluded that PNUTGRO can be ised to predict groundnut yields as influenced by water Ivailability, sowing dates, and seasons. Simulation of ong-term yield of groundnut cultivar TMV 2 showed hat simulated pod yields followed a similar trend as sbserved yields (Fig. 9). The differences between bserved and simulated yields were less than $300 \mathrm{~kg}$ / la in most years, except for 1982 and 1985 . These lifferences in yields are attributed to the differences in sop management other than sowing dates. This analisis further confirms that PNUTGRO can be used to prelict changes in yield caused by variation in seasons, owing dates and moisture availability.

\section{j. Conclusions}

The groundnut model PNUTGRO was calibrated, ested, and validated to predict crop yields as influenced sy season, sowing date, and moisture regimes. The nodel validation results showed that simulated days to rarious growth stages, growth processes, and final rields were significantly correlated with the observed lata across environments. It is concluded from this study that the model PNUTGRO can be confidently used to determine potential yields of environments as influenced by season and sowing dates under both optimal and sub-optimal levels of water availability. Further studies are needed to improve predictions of vegetative development and pod-growth as influenced by various soil and climatic stresses not already considered in the model. As diseases and pests are also major reducers of yield in groundnut, their effects need to be incorporated in the model.

\section{Acknowledgements}

We thank M/s S. Ramakrishna, R. Mukunda Reddy, Y.V. Srirama and B.N. Reddy for their assistance in conducting field experiments and data management. We also thank Mr. K.N.V. Satyanarayana for typing this manuscript and the anonymous referees for their comments and suggestions to improve this manuscript. Submitted as journal Article No. 1618 by the International Crops Research Institute for the Semi-Arid Tropics (ICRISAT),

\section{References}

Boote, K.J., 1982. Growth stages of peanut (Arachis hypogeaea L.). Peanut Sci., 9: 35-40.

Boote, K.J. and Jones, J.W., 1988. Applications of, and limitations to, crop growth simulation models to fit crops and cropping systems to semi-arid environments. In: F.R. Bidinger and C. Johansen (Editors), Drought Research Priorities for the Dryland Tropics. International Crops Research Institute for the Semi-Arid Tropics, Patancheru, India, pp. 63-75.

Boote, K.J., Jones, J.W., Mishoe, J.W. and Wilkerson, G.G., 1986. Modeling growth and yield of groundnut. In: Agrometeorology of Groundnut. Proceedings of an International Symposium, ICRISAT Sahelian Center, Niamey, Niger, 21-26 August 1985. International Crops Research Institute for the Semi-Arid Tropics, Patancheru, India, pp. 243-254.

Boote, K.J., Jones, J.W., Hoogenboom, G. and Wilkerson, G.G., 1987. PNUTGRo v1 .0, Peanut crop growth and yield model. Technical documentation. Department of Agronomy and Agricultural Engineering, University of Florida, Gainesville, FL, 121 pp.

Boote, K.J., Jones, J.W., Hoogenboom, G., Wilkerson, G.G. and Jagtap, S.S., 1989. PNUTGRo V1.02, Peanut crop growth simulation model. User's Guide. Florida Agricultural Experiment Station Journal No. 8420, Gainesville, FL, 76 pp.

Boote, K.J., Jones, J.W. and Singh, P., 1992. Modeling growth and yield of groundnut. In: S.N. Nigam (Bditor), Groundmut - A Global Perspective. Proceedings of an International Workshop, 
ICRISAT Center, Patancheru, India, 25-29 November 1991. International Crops Research Institute for the Semi-Arid Tropics, Patancheru, India, pp. 331-343.

IBSNAT (International Benchmark Soils Network for Agrotechnology Transfer), 1989. Decision Support System for Agrotechnology Transfer (DSSAT), V2.1. Documentation of IBSNAT crop model minimum data set entry and retrieval. IBSNAT Project, Department of Agronomy and Soil Science, University of Hawaii, Honolulu, $\mathrm{HI}$.

Isleib, T.G. and Wynne, J.C., 1992. Groundnut production and research in North America. In: S.N. Nigam (Editor), Groundnut - A global perspective. Proceedings of an International Workshop, ICRISAT Center, Patancheru, India, 25-29 November 1991. International Crops Research Institute for the Semi-Arid Tropics, Patancheru, India, pp. 57-76.

Jones, C.A. and Kiniry, J.R. (Editors), 1986. Ceres-Maize: A simulation Model of Maize Growth and Development. Texas A and M University Press, College Station, Texas, 194 pp.
Priestley, C.H.B. and Taylor, R.J., 1972. On the assessment of surface heat and evaporation using large scale parameters. Monthly Weather Review, 100: 81-92.

Ritchie, J.T., 1972. Model for predicting evaporation from a row with incomplete cover. Water Resour. Res., 8: 1204-1213.

Ritchie, J.T., 1985. A user-oriented model of the soil water balance in wheat. In: W. Day and R.K. Atkin (Editors), Wheat Growth and Modeling. Plenum, New York, pp. 293-305.

USDA Soil Conservation Service, 1972. National Engineering Handbook, Hydrology Section 4, Chapter 4-10.

Virmani, S.M., Faris, D.G. and Johansen, C. (Editors), 1991. Agroclimatology of Asian Grain Legumes (Chickpea, Pigeonpea, and Groundnut). Research Bulletin no. 14. International Crops Research Institute for the Semi-Arid Tropics, Patancheru, India. $77 \mathrm{pp}$.

Wilkerson, G.G., Jones, J.W., Boote, K.J., Ingram, K.T. and Mishoe, J.W., 1983. Modeling soybean growth for crop management. Trans. ASAE, 26: 63-73. 